\title{
Penerapan Metode Inkuiri Melalui Pemanfaatan Media Powerpoint Berbasis Mandiri untuk Meningkatkan Motivasi dan Prestasi Belajar Biologi
}

\author{
I Gusti Putu Agung Arimbawa ${ }^{1 *}$ (iD \\ ${ }^{1}$ Sekolah Menengah Atas Negeri 1 Petang, Indonesia \\ *Corresponding author: arimbawaagung76@gmail.com
}

\begin{abstract}
Abstrak
Penelitian ini bertujuan untuk menganalisis efektifitas metode inkuiri melalui pemanfaatan media pawerpoint berbasis mandiri terhadap meningkatkan motivasi dan Prestasi belajar biologi. Penelitian ini merupakan penelitian tindakan kelas (classroom action research), dengan sampel penelitian seluruh siswa kelas XI IPA 3 yang berjumlah 26 orang. Data motivasi belajar dikumpulkan melalui angket motivasi belajar dengan menggunakan skala Likert (1-5) dan data prestasi belajar siswa dikumpulkan melalui tes prestasi belajar yang disusun dalam bentuk tes objektif dengan skala 100. Data yang telah terkumpul, kemudian dianalisis secara diskriptif. Hasil penelitian menunjukkan: 1) terjadi peningkatan motivasi belajar Biologi siswa kelas XI. Rata-rata motivasi belajar Biologi siswa sebesar 80,15 dengan kategori tinggi pada siklus I, dan mengalami peningkatan pada siklus II menjadi 85,85 dengan kategori sangat tinggi; 2) terjadi peningkatan prestasi belajar biologi siswa kelas XI IPA 3 tahun pelajaran 2019/2020 melalui implementasi metode inkuiri melalui pembuatan powerpoint). Rata-rata prestasi belajar biologi siswa sebesar 68,40 dengan kategori cukup pada siklus I, dan mengalami peningkatan pada siklus II menjadi 89,00 dengan kategori sangat baik. Jadi, terdapat pengaruh metode inkuiri melalui pemanfaatan media pawerpoint berbasis mandiri terhadap meningkatkan motivasi dan Prestasi belajar biologi.
\end{abstract}

Kata Kunci: Inkuiri, Powerpoint, Motivasi Belajar, Prestasi Belajar

\section{Abstract}

This study aims to analyze the effectiveness of the inquiry method through the use of independent based power point media to increase motivation and learning achievement in biology. This research is a classroom action research, with a sample of all 26 students in XI IPA 3 Class. Learning motivation data were collected through a learning motivation questionnaire using a Likert scale (1-5) and student achievement data were collected through learning achievement tests which were arranged in the form of an objective test with a scale of 100. The collected data were then analyzed descriptively. The results showed: 1) there was an increase in students' motivation to learn Biology class XI. The average student motivation to learn Biology is 80.15 with the high category in cycle I, and experienced an increase in cycle II to be 85.85 in the very high category; 2) there was an increase in the learning achievement of XI IPA 3 student for the 2019/2020 academic year through the implementation of the inquiry method through making powerpoints). The average student learning achievement for biology was 68.40 in the sufficient category in the first cycle, and an increase in the second cycle to 89.00 in the very good category. So, there is an effect of the inquiry method through the use of self-based powerpoint media on increasing motivation and learning achievement in biology. 40 in the moderate category in the first cycle, and an increase in the second cycle to 89.00 in the very good category. So, there is the influence of the inquiry method through the use of selfbased powerpoint media on increasing motivation and learning achievement in biology. 40 in the moderate category in the first cycle, and an increase in the second cycle to 89.00 in the very good category. So, there is an effect of the inquiry method through the use of self-based powerpoint media on increasing motivation and learning achievement in biology

Keywords: Inquiry, Powerpoint, Learning Motivation and Learning Achievement

$\begin{array}{lll}\text { History: } & & \text { Publisher: Undiksha Press } \\ \text { Received } & : 3 \text { August } 2020 & \text { Licensed: This work is licensed under } \\ \text { Revised } & : \text { 1 September } 2020 & \text { a Creative Commons Attribution 3.0 License } \\ \text { Accepted } & : \text { : } 26 \text { September } 2020 & \text { CC C) OP } \\ \text { Published } & : \text { 1 Desember } 2020 & \end{array}$




\section{Introduction}

Biologi merupakan ilmu pengetahuan alam yang mempelajari tentang kehidupan dari segala aspek. Pembelajarn biologi bukan hanya sebagai penguasaan kumpulan pengetahuan yang berupa fakta, konsep atau prinsip, tetapi juga merupakan suatu proses penemuan (Aisyah \& Lokaria, 2019; Febrianti et al., 2018). Pembelajaran pembelajaran biologi lebih banyak menghafalkan fakta, prinsip, dan teori saja, sehingga diperlukan inovasi pembelajaran untuk mengoptimalkan hasil pembelajaran biologi (Wahyuningsih \& Murwani, 2015). Pembelajaran biologi tidak cukup disampaikan dalam pembelajaran dikelas hanya melalui transfer pengetahuan dari guru ke siswa namun perlu diberikan pengalaman belajar yang mendorong siswa untuk berpikir lebih dalam tentang materi yang ada. Dengan adanya inovasi tersebut di atas dituntut seorang guru untuk lebih kreatif dan inovatif, sehingga tolak ukur dalam pembelajaran tidak hanya bertumpu pada hasil namun juga pada saat proses belajar itu berlangsung (Candrawati, 2020; Harahap et al., 2018).

Namun, kondisi dilapangan berbeda, hasil belajar siswa pada tema Sistem Kekebalan tubuh Manusia di SMA Negeri 1 Petang tergolong rendah, seperti yang terjadi di kelas XI IPA3. Hal ini dapat dilihat dari profil kompetensi dasar Biologi pada Tema Sistem Kekebalan tubuh Manusia dalam aspek kognitif, psikomotor, dan afektif yang dicapai siswa dua tahun terakhir relatif masih rendah. Pada tahun pelajaran 2017/2018 nilai kognitif sebesar 66,07, psikomotor 70,00 dengan afektif cukup. Tahun pelajaran 2018/2019 kognitif 67,54, psikomotor 75,00 afektif cukup. Rendahnya penguasaan kompetensi dasar Biologi yang dicapai siswa merupakan refleksi dari rendahnya kualitas pembelajaran sains khususnya Biologi di SMA Negeri 1 Petang.

Berdasarkan hasil observasi terhadap siswa, dapat diketahui bahwa rendahnya kualitas pembelajaran biologi bersumber pada : 1) kurang efektifnya proses pembelajaran. Dalam proses pembelajaran lebiih cenderung guru sebagai penceramah dan sedikit memberikan kesempatan untuk berkembangnya siswa sesuai dengan skill yang dimiliki sehingga tingkat kebosanan siswa timbul dan motivasi siswa menjadi sangat rendah. Untuk itulah diperlukan kreativitas guru dalam memngembangkan proses pembelajaran, 2) metode pembelajaran yang digunakan belum tepat dan belum berdasarkan kebutuhan dari kelas bersangkutan, tetapi lebih karena tuntutan materi. Tuntutan materi yang dimaksud adalah segera bisa diselesaikannya setiap kompotensi dasar sesuai waktu dalam kalender akademik tanpa memperhatikan daya tangkap dan kemampuan dari siswa, 3) siswa kurang fokus pada saat menerima pelajaran dan lebih banyak melakukan aktivitas di luar aspek pembelajaran, misalnya ramai, celometan, kipas-kipas, berbicara sendiri dengan teman sebangku, 4) banyak siswa yang tidak memiliki buku acuan yang diberikan guru, hanya sebagian kecil yang punya karena keterbatasan dana sehingga siswa kurang dalam penguasaan konsep, 5) dalam pembelajaran guru lebih menekankan pada hasil pembelajaran yang akan dicapai daripada proses pembelajaran yang berlangsung, 6) sarana prasarana yang ada belum digunakan, misalnya sudah ada LCD tetapi belum digunakan secara optimal, 7) belum tampak adanya inovasi atau pembaharuan pembelajaran sehingga kualitas proses pembelajaran belum sepenuhnya terlaksana dengan optimal.

Untuk mengantisipasi hal tersebut perlu dikembangkan strategi pembelajaran biologi yang dapat melibatkan siswa secara aktif dalam kegiatan pembelajaran untuk menemukan dan menerapkan ide-ide mereka. Salah satu model pembelajaran yang dapat diterapkan adalah dengan menerapkan Metode inkuiri melalui Pemanfaatan Media Power Point Berbasis Mandiri pada Tema Sistem Kekebalan Tubuh manusia.

Metode pembelajaran sampai saat ini masih tetap dianggap sebagai metode yang cukup efektif dalam bidang Sains adalah metode pembelajaran metode inquiri. metode pembelajaran inquiri adalah suatu rangkaian kegiatan pembelajaran yang melibatkan secara 
maksimal seluruh kemampuan peserta didik untuk mencari dan menyelidiki secara sistematis, kritis dan logis sehingga dapat menemukan sendiri pengetahuan, sikap dan ketrampilan sebagai wujud adanya perubahan perilaku (Andoko, 2020; Christopel \& Kuntoro, 2016; Ruspa, 2019). Pembelajaran inkuiri membangkitkan minat dengan rasa penasaran yang mendalam. Inkuiri adalah model pembelajaran yang dikembangkan oleh seorang tokoh yang bernama Schuman yang meyakini bahwa anak-anak merupakan individu yang penuh dengan rasa ingin tahu akan segala sesuatu (Isrianto, 2016; Mohammad et al., 2017). Berdasarkan uraian di atas dapat disimpulkan bahwa metode pembelajaran inkuiri adalah suatu rangkaian kegiatan belajar yang melibatkan seluruh kemampuan siswa untuk mencari dan menyelidiki secara sistematis, kritis, logis, analitis, sehingga mereka dapat merumuskan sendiri penemuannya dengan penuh percaya diri.

Selain model pembelajaran, peningkatan motivasi dan hasil belajar dapat diterapkan sebuah media pembelajaran. Media pembelajaran adalah seluruh alat dan bahan yang dapat dipakai untuk mencapai tujuan pendidikan seperti radio, televisi, buku, koran, majalah dan sebagainya (Suwitri et al., 2013). Media pembelajaran adalah segala sesuatu yang dapat digunakan untuk menyalurkan pesan dari pengirim ke penerima sehingga merangsang pikiran, perasaan, perhatian, dan minat serta kemauan peserta didik sedemikian rupa sehingga proses belajar terjadi dalam rangka mencapai tujuan pembelajaran secara efektif (Agustini et al., 2016; Dwiki Setya Prayoga et al., 2020). Salah satu media yang bisa digunakan adalah media powerpoint. Powerpoint terdapat banyak fitur yang dapat dimanfaatkan untuk berkreasi dalam media pembelajaran yang menarik, interaktif dan menyenangkan beberapa fasilitas yang disediakan oleh program powerpoint yaitu template, custom show, office art, grafik file format, delivering presentasion, animasi (Mawaddah et al., 2019; Yuliansah, 2018)

Jadi, dengan adanya kolaborasi antara metode inkuiri dan media powerpoint dapat meningkatkan motivasi dan hasil belajar. Hal ini sesaui dengan penelitian yang dilakukan oleh Uliyandari \& Lubis, (2020) hasil penelitian menunjukkan bahwa penggunaan model inkuiri dan media alat peraga dapat meningkatkan hasil belajar siswa pada pembelajaran IPA di SDN 013 Bengkulu Utara. hal ini disebabkan penggunaan model pembelajaran inkuiri dengan media alat peraga dapat meningkatkan motivasi belajar siswa sehingga berpengaruh pada peningkatan hasil belajar siswa. Penelitian Mohammad et al., (2017) menunjukkan hasil evaluasi aktivitas siswa dalam pembelajaran inkuiri yang menunjukkan peningkatan pada setiap pertemuan. Siklus I dan II terjadi peningkatan siswa yang mendapat predikat kompeten. Hasil tes evalusi siklus I sebanyak 21 siswa, naik menjadi 27 siswa. Penelitian Hasana \& Maharany, (2017) menunjukkan Hasil Penelitian ini adalah suatu produk multimedia yang dapat membantu guru dalam mengembangkan karya inovatif yang mendukung profesionalismenya sebagai guru.

Tujuan penelitian menganalisis efektifitas metode inkuiri melalui pemanfaatan media pawerpoint berbasis mandiri terhadap meningkatkan motivasi dan Prestasi belajar biologi. Dengan adanya kolaborasi metode inkuiri dengan media powerpoint dapat meningkatkan motivasi dan prestasi anak. Karena dengan adanya kolaborasi ini dapat membuat suanana menarik dan lebiah meyenangkan.

\section{Materials and Methods}

Penelitian dilaksanakan di SMA N 1 Petang, dengan melibatkan siswa kelas XI IPA pada semester genap tahun pelajaran 2019/2020. Penelitian dimulai dari tanggal 12 April s/d 10 Mei 2019. Subyek dalam penelitian ini adalah XI IPA3. Banyaknya siswa 26 orang, dengan 12 orang siswa laki-laki, dan 13 orang siswa perempuan. Obyek dalam penelitian ini adalah motivasi belajar dan prestasi belajar biologi siswa, dengan materi Sistem Kekebalan Tubuh Manusia. Pelaksanaan pembelajaran akan dilakukan oleh guru Biologi yang mengajar di kelas XI IPA3 SMA N 1 Petang sebagai praktisi sekaligus peneliti. Penelitian ini 
menggunakan penelitian tindakan kelas atau class room action research, dengan mengikuti beberapa tahapan seperti yang dikemukakan Kemmis \& Taggart (1998), yaitu: (1) tahap perencanaan (planing); (2) tahap tindakan (action); (3) tahap observasi/ evaluasi (evaluation); dan (4) tahap refleksi (reflection), kemudian kembali lagi ke tahap perencanaan, tahap tindakan dan seterusnya sehingga membentuk siklus seperti di gambarkan pada gambar 01 . Penelitian ini dirancang sebanyak dua siklus, masing-masing siklus terdiri dari dua kali pertemuan dengan mengambil materi tentang motivasi belajar dianalisis secara diskriptif.

\section{Results and Discussion Hasil penelitian}

Berdasarkan penelitian yang telah dilaksanakan sebanyak dua siklus, menunjukkan adanya peningkatan motivasi dan prestasi belajar biologi siswa. Berdasarkan analisis data pada siklus I di peroleh bahwa skor rata-rata motivasi belajar biologi siswa sebesar 80,15 dengan kategori tinggi dan skor rata-rata prestasi belajarnya sebesar 68.40 dengan kategori cukup, daya serap sebesar $68 \%$ dan ketuntasan klasikalnya 57,78\%. Hasil analisis data menunjukkan bahwa penelitian ini belum berhasil. Indicator keberhasilan prestasi belajar jika berada dalam kategori baik/ nilai rata-rata prestasi belajar kelas sekurang-kurangnya 78 dan motivasi belajar siswa berada pada kategori tinggi.

Berdasarkan pengamatan, banyaknya siswa yang memperoleh nilai prestasi belajar yang cukup diakibatkan oleh beberapa faktor yaitu : 1) siswa belum terbiasa belajar dengan menemukan sendiri konsep yang dipelajari, sehingga hasil pembuatan power point yang dihasilkan belum maksimal, 2) siswa belum terbiasa menggunakan powerpoint sebagai sarana belajar, dan terkesan siswa menunggu arahan atau penjelasan guru, 3) siswa belum terbiasa untuk mengubah pola belajar mereka yakni guru sebagai sumber informasi, 4) beberapa siswa belum memaksimalkan fungsi laptop dan fasilitas lainnya yang mendukung, sehingga beberapa slide tidak jelas, 5) siswa belum memaksimalkan fasilitas internet gratis dalam menggali informasi, dan masih mengandalkan satu buku sumber sehingga informasi yang dihasilkan tidak optimal, 7) beberapa siswa masih bingung dengan konsep yang ditemukannya, sehingga penjelasan dalam powerpoint yang dihasilkan masih membingungkan.

Berdasarkan kendala tersebut, dilakukan beberapa perbaikan tindakan terhadap proses pembelajarannya, dengan melakukan kegiatan sebagai berikut: (1) sebelum pelaksanaan tindakan siklus II, guru/peneliti menekankan kembali mengenai pembelajaran, baik langkah pembelajaran, maupun aspek-aspek yang terkait dengan penilaian sehingga siswa lebih aktif dan kreatif dalam proses pembelajarannya; (2) guru menekankan pembuatan powerpoint untuk proses pembelajaran guna meminimalisir salah penggunaan, (3) guru memberikan tugas pada masing-masing kelompok untuk membuat powerpoint pembelajaran di rumah.

Motivasi belajar pada siklus I menunjukkan bahwa implementasi metode inkuiri melalui pemanfaatan powerpoint sudah dapat meningkatkan motivasi belajar biologi siswa. Hal ini dikarenakan, siswa senang dapat mengeksplorasi konsepnya sendiri dengan menggunakan peralatannya sendiri walaupun konsep yang ditemukan dan disampaikan belum sepenuhnya benar, dan siswa mampu merealkan konsep-konsep abstrak pada waktu pembelajaran melalui investigasi langsung. Hal ini memunculkan kebermaknaan dalam belajar yang pada akhirnya mampu meningkatkan motivasi belajar.

Setelah diadakan perbaikan pada siklus II, perolehan nilai motivasi belajar dan prestasi belajar siswa mengalami peningkatan. Rata-rata motivasi belajar biologi siswa sebesar 85.85 dengan kategori sangat tinggi dan skor rata-rata prestasi belajarnya sebesar 89.00 dengan kategori sangat baik, daya serap sebesar $80 \%$ dan ketuntasan klasikalnya $100 \%$. Dari kategori yang ditetapkan maka penelitian ini sudah mencapai kategori keberhasilan, yakni : indicator keberhasilan prestasi belajar berada dalam kategori baik/ nilai rata-rata prestasi 
belajar kelas sekurang-kurangnya 78 dan motivasi belajar siswa berada pada kategori tinggi. Berdasarkan hal tersebut, maka dapat disimpulkan bahwa implementasi metode inkuiri melalui pemanfaatan powerpoint mampu meningkatkan motivasi dan prestasi belajar biologi siswa kelas XI IPA 3 SMA Negeri 1 Petang tahun pelajaran 2019/2020.

Metode pembelajaran sampai saat ini masih tetap dianggap sebagai metode yang cukup efektif dalam bidang Sains adalah metode pembelajaran metode inquiri. metode pembelajaran inquiri adalah suatu rangkaian kegiatan pembelajaran yang melibatkan secara maksimal seluruh kemampuan peserta didik untuk mencari dan menyelidiki secara sistematis, kritis dan logis sehingga dapat menemukan sendiri pengetahuan, sikap dan ketrampilan sebagai wujud adanya perubahan perilaku (Andoko, 2020; Christopel \& Kuntoro, 2016; Ruspa, 2019). Pembelajaran inkuiri membangkitkan minat dengan rasa penasaran yang mendalam. Inkuiri adalah model pembelajaran yang dikembangkan oleh seorang tokoh yang bernama Schuman yang meyakini bahwa anak-anak merupakan individu yang penuh dengan rasa ingin tahu akan segala sesuatu (Isrianto, 2016; Mohammad et al., 2017). Berdasarkan uraian di atas dapat disimpulkan bahwa metode pembelajaran inkuiri adalah suatu rangkaian kegiatan belajar yang melibatkan seluruh kemampuan siswa untuk mencari dan menyelidiki secara sistematis, kritis, logis, analitis, sehingga mereka dapat merumuskan sendiri penemuannya dengan penuh percaya diri.

Selain model pembelajaran, peningkatan motivasi dan hasil belajar dapat diterapkan sebuah media pembelajaran. Media pembelajaran adalah seluruh alat dan bahan yang dapat dipakai untuk mencapai tujuan pendidikan seperti radio, televisi, buku, koran, majalah dan sebagainya (Suwitri et al., 2013). Media pembelajaran adalah segala sesuatu yang dapat digunakan untuk menyalurkan pesan dari pengirim ke penerima sehingga merangsang pikiran, perasaan, perhatian, dan minat serta kemauan peserta didik sedemikian rupa sehingga proses belajar terjadi dalam rangka mencapai tujuan pembelajaran secara efektif (Agustini et al., 2016; Dwiki Setya Prayoga et al., 2020). Salah satu media yang bisa digunakan adalah media powerpoint. Powerpoint terdapat banyak fitur yang dapat dimanfaatkan untuk berkreasi dalam media pembelajaran yang menarik, interaktif dan menyenangkan beberapa fasilitas yang disediakan oleh program powerpoint yaitu template, custom show, office art, grafik file format, delivering presentasion, animasi (Mawaddah et al., 2019; Yuliansah, 2018)

\section{Pembahasan}

Dengan adanya kolaborasi antara metode inkuiri dan media powerpoint dapat meningkatkan motivasi dan hasil belajar. Hal ini sesaui dengan penelitian yang dilakukan oleh Uliyandari \& Lubis, (2020) hasil penelitian menunjukkan bahwa penggunaan model inkuiri dan media alat peraga dapat meningkatkan hasil belajar siswa pada pembelajaran IPA di SDN 013 Bengkulu Utara. hal ini disebabkan penggunaan model pembelajaran inkuiri dengan media alat peraga dapat meningkatkan motivasi belajar siswa sehingga berpengaruh pada peningkatan hasil belajar siswa. Penelitian Mohammad et al., (2017) menunjukkan hasil evaluasi aktivitas siswa dalam pembelajaran inkuiri yang menunjukkan peningkatan pada setiap pertemuan. Siklus I dan II terjadi peningkatan siswa yang mendapat predikat kompeten. Hasil tes evalusi siklus I sebanyak 21 siswa, naik menjadi 27 siswa. Penelitian Hasana \& Maharany, (2017) menunjukkan Hasil Penelitian ini adalah suatu produk multimedia yang dapat membantu guru dalam mengembangkan karya inovatif yang mendukung profesionalismenya sebagai guru.

Beberapa temuan dalam penelitian ini adalah : (1) implementasi metode inkuiri melalui pemanfaatan powerpoint mampu mengkaitkan konsep-konsep biologi secara real bagi siswa, dengan menemukan sendiri materi/konsep yang dipelajari sendiri akan meningkatkan kemampuan sains siswa, (2) siswa mampu dan terbiasa dalam melakukan penyelidikan dan investigasi autentik untuk mencari penyelesaian maslah secara nyata, (3) siswa dapat 
mengeksplorasi ide-ide dalam pemikirannya tentang materi yang dipelajari, dan mampu menghasilkan produk atau karya dan mempresentasikannya atau memamerkannya, (4) siswa akan terlatih dalam hal sosial kebersamaan (dengan berkelompok 4-5 orang) dalam melakukan investigasi, sehingga dapat menumbuhkan aspek sosial, interpersonal dan interapersonal. Beberapa manfaat yang dapat diambil dari penelitian ini yaitu: (1) implementasi metode inkuiri melalui pemanfaatan powerpoint dapat memberikan pengalaman baru dan menyenangkan baik bagi guru maupun siswa; (2) siswa dapat mengejar ketertinggalan pengetahuan tentang Iptek di bidang pendidikan; (3) dapat meningkatkan motivasi belajar para pembelajar; (4) dapat digunakan untuk membantu membentuk model mental yang akan memudahkan pembelajar memahami suatu konsep.

\section{Conclusion}

Dari hasil analisis dan pembahasan tentang implementasi metode inkuiri melalui pemanfaatan powerpoint dapat disimpulkan sebagai berikut. 1) Implementasi metode inkuiri melalui pemanfaatan powerpoint dapat meningkatkan motivasi belajar biologi siswa kelas XI IPA 3 SMA N 1 Petang tahun pelajaran 2019/2020. Rata-rata motivasi belajar biologi siswa sebesar 80.15 dengan kategori tinggi pada siklus I, dan mengalami peningkatan pada siklus II menjadi 85. 85 dengan kategori sangat tinggi, 2) Implementasi metode inkuiri melalui pemanfaatan powerpoint dapat meningkatkan prestasi belajar biologi siswa kelas XI IPA 3 SMA N 1 Petang tahun pelajaran 2019/2020. Rata-rata prestasi belajar biologi siswa sebesar 68.40 dengan kategori cukup pada siklus I, dan mengalami peningkatan pada siklus II menjadi 89.00 dengan kategori sangat baik.

\section{References}

Agustini, P. P., Kristiantari, M. . R., \& Putra, D. K. N. S. (2016). Penerapan Model Pembelajaran Berbasis Masalah Berbantuan Media Audio Visual Untuk Meningkatkan Hasil Belajar Keterampilan Menyimak Tema Sejarah Peradaban Indonesia Pada Siswa $\begin{array}{lllllll}\text { Kelas } & \mathrm{V} & \mathrm{Sdn} & 8 & \text { Sumerta. MIMBAR } & \text { PGSD Undiksha, 4(1). }\end{array}$ https://doi.org/10.23887/jjpgsd.v4i1.7265

Aisyah, S., \& Lokaria, E. (2019). ANALISIS HASIL BELAJAR BIOLOGI SISWA KELAS $X$ PROGRAM IPS : DAMPAK MODEL PEMBELAJARAN PROBLEM POSING. BIOSFER: Jurnal Tadris Biologi Vol., 10(2), 95-107. http://ejournal.radenintan.ac.id/index.php/biosfer/index\%0Ap-ISSN

Andoko, T. H. (2020). Peningkatan Hots Dan Prestasi Belajar Melalui Metode Inkuiri Kelas 7C Smpn 1 Wonosobo Tahun Pelajaran 2018/2019. SPEKTRA: Jurnal Kajian Pendidikan Sains, 6(1), 92. https://doi.org/10.32699/spektra.v6i1.134

Candrawati, E. (2020). PENERAPAN MODEL DIRECT INTRUCTION UNTUK MENINGKATKAN HASIL BELAJAR BIOLOGI. Jurnal Educatio FKIP UNMA, 6(1), 140-146. https://doi.org/https://doi.org/10.31949/educatio.v6i1.287

Christopel, C., \& Kuntoro, S. A. (2016). Pemahaman Nilai-Nilai Demokrasi Siswa Melalui Metode Inquiri Pada Pembelajaran Pkn Di Sma Negeri 1 Gamping Sleman. Harmoni Sosial: Jurnal Pendidikan IPS, 3(1), 14-26. https://doi.org/10.21831/hsjpi.v3i1.9697

Dwiki Setya Prayoga, Lodra, I. N., \& Abdillah, A. (2020). Perancangan Audio Visual Sebagai Media Propaganda Dalam Pelestarian. Jurnal Brikolase, 11(2), 115-128. https://doi.org/https://doi.org/10.33153/brikolase.v11i2.2829

Febrianti, E. S., Karyadi, B., \& Kasrina, K. (2018). Penerapan Model Kooperatif Tipe-Group 
Investigation (Gi) Pada Materi Sistem Ekskresi Manusia Untuk Meningkatkan Hasil Belajar Siswa Kelas Xi Ipa Sma N 8 Kota Bengkulu. Diklabio: Jurnal Pendidikan Dan Pembelajaran Biologi, 2(1), 10-14. https://doi.org/10.33369/diklabio.2.1.10-14

Harahap, khairuddin ahmad didayah, Nasution, wahyuddin nur, \& Mardianto. (2018). Inovasi Pembelajaran Pendidikan Agama Islam ( Pai ) Di Sekolah Dasar Negeri 097523 Perumnas Batu Vi Kecamatan Siantar Kabupaten Simalungun. Edu Riligia, 2, 275-290.

Hasana, S. N., \& Maharany, E. R. (2017). Pengembangan Multimedia Menggunakan Visual Basic for Application (Vba) Untuk Meningkatkan Profesionalisme Guru Matematika. JPM : Jurnal Pendidikan Matematika, 3(2), 30. https://doi.org/10.33474/jpm.v3i2.648

Isrianto, P. L. (2016). Pembelajaran Inkuiri Melalui Bertanam Limbah Sayuran untuk Mengembangkan Sikap Ilmiah Mahasiswa Pendidikan Biologi UWKS Pada Matakuliah Bercocok Tanam. Jurnal Inovasi Pembelajaran, 2(2), 407-416. https://doi.org/https://doi.org/10.22219/jinop.v2i2.3279

Mawaddah, W., Ahied, M., Hadi, W. P., Yuniasti, A., \& Wulandari, R. (2019). Uji Kelayakan Multimedia Interaktif Berbasis Powerpoint Disertai Permainan Jeopardy Terhadap Motivasi Belajar Siswa. Natural Science Education Reseach, 2(2), 26544210. https://eco-entrepreneur.trunojoyo.ac.id/nser/article/view/6254

Mohammad, F. H., Suwignyo, H., \& Mudiono, A. (2017). Penerapan Model Inkuiri untuk Meningkatkan Aktivitas dan Hasil Belajar IPA pada Siswa KELAS V. Jurnal Pendidikan - Teori, Penelitian, Dan Pengembangan, 1, 20-29. https://doi.org/http://dx.doi.org/10.17977/jptpp.v2i12.10315

Ruspa, A. R. (2019). Penerapan Model Inquiri pada Pembelajaran Menulis Karangan Eksposisi Siswa Kelas VIII SMP Negeri 1 Sabbang Kabupaten Luwu Utara. Jurnal Studi Guru Dan Pembelajaran, 2(3), 210-220. https://doi.org/10.30605/jsgp.2.3.2019.7

Suwitri, N. P. D., Ardana, I. K., \& Negara, I. G. A. O. (2013). Pengaruh Pembelajaran Mind Mapping Berbantuan Media Konkret Terhadap Hasil Belajar IPA Siswa Kelas V SD Gugus III Banjar Anyar Kediri. Mimbar PGSD, 1(1). https://doi.org/http://dx.doi.org/10.23887/jjpgsd.v1i1.1251

Uliyandari, M., \& Lubis, E. E. (2020). Penerapan Model Pembelajaran Inkuiri Dan Media Alat Peraga (Gunung Berapi) Pada Mata Pelajaran IPA SDN 013 Bengkulu Utara. PENDIPA Journal of Science Education, 4(2), 74-78. https://doi.org/10.33369/pendipa.4.2.74-78

Wahyuningsih, D., \& Murwani, S. (2015). Peningkatan Aktivitas dan Hasil Belajar Siswa pada Pembelajaran Biologi Melalui Implementasi Model Numbered Head Together pada Siswa Kelas XI SMA Negeri 2 Yogyakarta. Jurnal Pendidikan Matematika Dan Sains, 3(1), 65-71. https://doi.org/10.21831/jpms.v5i1.7237

Yuliansah. (2018). Efektivitas Media Pembelajaran Powerpoint Berbasis Animasi. Jurnal Efisiensi, $X V(2)$, $24-32$. https://jurnal.untirta.ac.id/index.php/Candrasangkala/article/download/2886/2253. 